\title{
MENGIDENTIFIKASI FAKTOR YANG MEMPENGARUHI PENINGKATAN MIGRASI INTERNASIONAL DI DESA MEKAR DAMAI KECAMATAN PRAYA KABUPATEN LOMBOK TENGAH TAHUN 2015
}

\author{
${ }^{1}$ Mas'ad, ${ }^{2}$ M. Nizar, ${ }^{3}$ Faridatul Aini \\ ${ }^{1,2,3}$ Dosen Program Studi Pendidikan Geografi, Universitas Muhammadiyah Mataram \\ Email : siti.masad@yahoo.com
}

\begin{abstract}
ABSTRAK
Migrasi internasional didefenisikan sebagai sebuah bentuk mobilitas penduduk yang melampaui batas-batas wilayah Negara dan budaya. Aktifitas migrasi internasional, masyarakat desa Mekar Damai mengalami peningkatan setiap tahunnya, hal ini disebabkan oleh kondisi sosial, pendidikan dan ekonomi masyarakat yang masih rendah, sementara harga barang kebutuhan semakin mahal dan rata-rata masyarakat bermata pencaharian sebagai buruh tani yang gajinya tidak mencukupi kebutuhan. Rumusan masalah penelitian ini adalah Faktor Apa Saja yang Mempengruhi Peningkatan Migrasi Internasional di Desa Mekar Damai Kecamatan Praya Kabupaten Lombok Tengah?.Tujuan penelitian ini adalah Untuk mengidentifikasi faktor yang mempengaruhi peningkatan migrasi internasional di Desa Mekar Damai Kecamatan Praya Kabupaten Lombok Tengah. Metode penelitian yang digunakan dalam penelitian ini adalah metode penelitian kualitatif. Metode penentuan informan dalam penelitian ini menggunakan purrposive sampling, dengan iforman kunci orang yang pernah melakukan migrasi internasional dan orang yang akan pergi migrasi internasional sedangkan informan biasa, kepala desa, tetangga dan keluarga dekat migran. Jenis data yang digunakan adalah jenis data kualitatif sedangkan sumber datanya adalah sumber data primer dan sekunder, metode pengumpulan data ialah metode observasi, dokumentasi dan wawancara. Teknik analisis data melalui langkahlangkah: reduksi data, penyajian data, dan penarikan kesimpulan. Berdasarkan analisis data, maka diperoleh kesimpulan yaitu: faktor yang mempengaruhi peningkatan migrasi internasional masyarakat Desa Mekar Damai Kacamatan Praya Kabupaten Lomok Tengah (1) faktor sosial (2) faktor pendidikan (3) faktor ekonomi, dari ketiga faktor tersebut yang paling berpengaruh adalah faktor ekonomi.
\end{abstract}

Kata kunci: Faktor yang mempengaruhi peningkatan migrasi internasional

\section{PENDAHULUAN}

Fenomena migrasi pekerja Indonesia ke luar negeri sesungguhnya bukan persoalan baru, melainkan telah berlansung sejak lama. Sejarah mencatat bahwa migrasi penduduk antar Negara di kawasan Asia dan khususnya kawasan Asia Tenggara telah dimulai sejak zaman kolonial. Pada masa kolonial kebanyakan migrasi internsional bersifat paksaan dan cendrung permanen.

Migrasi dapat didefinisikan sebagai perpindahan penduduk dari suatu tempat ke tempat yang lain, baik sifatnya permanen (bertempat tinggal di tempat yang baru paling sedikit 340 hari) atau semi permanen (hanya tinggal selama 15 hari dihitung dari awal kepindahannya ke tempat tersebut), yang melewati batas administratif atau batas bagian dalam suatu Negara atau daerah atau juga melampaui batas politis atau batas Negara. Berdasarkan pengertian tersebut migrasi dapat dikategorikan menjadi dua jenis yakni migrasi internal dan migrasi internasional. Migrasi internal adalah gerakan penduduk baik yang dilakukan oleh individu maupun kelompok yang masuk dan keluar dari daerah asal penduduk tersebut ke daerah tujuan yang masih berada di dalam satu Negara. Sedangkan, migrasi internasional lebih mengacu pada perpindahan penduduk baik yang dilakukan oleh individu maupun kelompok yang melewati batas suatu Negara. Migrasi tenaga kerja Indonesia (TKI) merupakan bagian dari proses migrasi internasional. Terjadinya migrasi tenaga kerja internasional antara lain dikarenakan ketidak samaan tingkat upah yang terjadi secara global, hubungan ekonomi dengan negara penerimanya, termasuk juga masalah perpindahan modal, peran yang dimainkan oleh perusahaan multinasional, serta perubahan struktural dalam pasar kerja yang berkaitan dengan perubahan dalam pembagian kerja di tingkat internasional (international division of 
labour). Indonesia merupakan Negara pengirim (sending country) buruh migran terbesar kedua di Asia Tenggara setelah Filipina.

Fenomena migrasi internasional juga dirasakan oleh salah satu desa di Lombok Tengah yaitu Desa Mekar Damai. Desa Mekar Damai adalah desa yang kehidupan masyarakatnya mayoritas berpendapatan sebagai petani, namun banyak diantara masyarakatnya hanya menjadi buruh tani, alasannya karena mereka tidak punya lahan sendiri untuk bertani. Masyarakat di Desa Mekar Damai hidup dalam bayang-bayang menjadi buruh tani yang gajinya tidak seberapa, sehingga banyak diantara mereka yang menjadi pengangguran. Himpitan ekonomi yang semakin mencekik, kebutuhan keluarga semakin tinggi, dan keadaan hidup yang semakin memburuk, membuat masyarakat di desa ini terpaksa mencari pekerjaan diluar negeri. Di desa Mekar Damai dalam kurun waktu tiga tahun belakang ini mulai tahun 2012-2014 mengalami peningkatan angka migrai internasional yakni; tahun 2012 sejumlah 125 orang dan tahun 2013 terjadi kenaikan menjadi 173 orang sedangkan pada tahun 2014 naik menjadi 211 orang. Berdasarkan fenomena diatas, maka penulis tertarik melakukan penelitian dengan judul "Mengidentifikai Faktor Yang Mempengaruhi Peningkatan Migrasi Internasional di desa Mekar Damai Kecamatan Praya Kabupaten Lombok Tengah".

\section{LANDASAN TEORI}

A. Migrasi Internasional

Migrasi didefinisikan sebagai perpindahan penduduk dengan tujuan untuk menetap dari suatu tempat ke tempat lain yang melampaui batas politik/negara ataupun batas administrasi/batas bagian suatu Negara. Migrasi yang melampaui batas negara disebut dengan migrasi internasional sedangkan migrasi internal merupakan perpindahan penduduk yang terjadi dalam batas wilayah suatu negara, baik antar daerah atau pun antar propinsi (Befita,2014).

Beberapa studi migrasi menyimpulkan bahwa migrasi terjadi disebabkan oleh alasan ekonomi. Kondisi tersebut sesuai dengan model migrasi Todaro yang menyatakan bahwa arus migrasi berlangsung sebagai tanggapan terhadap adanya perbedaan pendapatan antara daerah asal dan daerah tujuan. Pendapatan yang dimaksud adalah pendapatan yang diharapkan (expected income) bukan pendapatan aktual. Menurut model Todaro, para migran membandingkan pasar tenaga kerja yang tersedia bagi mereka di daerah asal dan daerah tujuan, kemudian memilih salah satu yang dianggap mempunyai keuntungan maksimum yang diharapkan (expected gains Migrasi internasional didefenisikan sebagai sebuah bentuk mobilitas penduduk yang melampaui batas-batas wilayah Negara dan budaya. Pengertian yang lebih luas dikemukakan yang mendefenisikan migrasi internasional sebagai suatu aktifitas perpindahan penduduk yang mencakup aspek perubahan tempat tinggal, tujuan migrasi maupun keinginan-keinginan menetap atau tidak menetap didaerah tujuan. Berdasarkan konteks pelaku atau migran, PBB mendefenisikan bahwa migran internasional adalah seseorang yang tinggal diluar Negara asal tempat tinggalnya selama periode sekurang-kurangnya satu tahun. Migrasi merupakan salah satu bentuk mobilitas penduduk yang banyak di pilih oleh masyarakat. Migrasi biasanya terjadi antara desa-kota yang terjadi di suatu wilayah, karena di desa masingmasing orang rata-rata bermata-pencaharian sebagai petani (Bakar, 2014).

\section{B. Jenis Migrasi Internasional}

Migrasi Internasional

diklasifikasikan menjadi beberapa jenis tertentu, yaitu:

a) Migran tetap (penetap): termasuk para pekerja pendatang, dan keluarga yang kemudian menyusulnya.

b) Pekerja kontrak sementara: umumnya tidak atau semi terdidik/terlatih yang tinggal di negara penerima untuk jangka waktu tertentu, biasanya dua tahun

c) Para profesional dengan izin tinggal sementara: yakni tenaga terdidik/terlatih yang pindah dari satu negara ke negara lain, biasanya sebagai tenaga ahli, staf, atau karyawan dari organisasi internasional atau perusahan multi - internasional.

d) Migran ilegal (klandestin): yakni mereka yang masuk dan tinggal di negara penerima tanpa didukung dokumen serta ijin dari pihak yang berwenang.

e) Pencari suaka: yakni mereka yang masuk ke negara lain dengan mengajukan ijin tinggal atas dasar takut hukuman karena suku, agama, politik, keanggotaan organisasi, dan lain sebagainya.

f) Pengungsi: yakni mereka yang diakui sebagai pengungsi sesuai persyaratan dalam Konvensi PBB 1951 mengenai Status Pengungsi. Perang saudara dan penindasan 
merupakan sebab utama dari pengungsi yang murni (Yunita, 2007).

\section{Faktor-Faktor Pendorong Peningkatan Migrasi Internasional}

Faktor-Faktor Pendorong Peningkatan Migrasi Internasional adalah

1. Faktor Sosial

Apabila ditinjau dari aspek sosial, ekonomi dan budaya adalah remitan dan perubahan sikap, yaitu perubahan persepsi sikap dan etos kerja. Pada hakekatnya orang yang pergi ke luar negeri sebagian besar mempunyai hasrat, setidaknya mempunyai ikatan batin dengan keluarganya yang biasanya dinyatakan melalui arus kiriman yang berupa uang atau barang yang mereka peroleh dari Negara tujuan. Remitan merupakan sumber yang cukup penting yang digunakan untuk biaya pendidikan anakanaknya maupun keluarga dekatnya dan juga untuk keperluan akumulasi modal keluarga dan untuk keperluan yang bersifat konsumtif.

2. Faktor Pendidikan

Pendidikan merupakan salah satu faktor yang mempengaruhi produktivitas seseorang. Walaupun ada faktor-faktor yang turut mempengaruhi seperti status sosial ekonomi keluarga dan motifasi untuk menjadi lebih baik. Namun tidak dapat dipungkiri bahwa pendidikan adalah faktor utama yang menentukan kinerja seseorang.

3. Faktor Ekonomi

Adapun yang menjadi alasan mengapa masyarakat bermigrasi keluar negeri yang paling dominan adalah alasan ekonomi yaitu untuk mendapatkan upah yang lebih tinggi sehingga dapat membantu meningkatkan kesejahteraan rumah tangganya.Dengan bekerja diluar negeri, maka pendapatan angaktan tenaga kerja bersama dengan keluarganya dapat ditingkatkan secara subtansi.

\section{METODE PENELITIAN}

Metode yang digunakan dalam penelitian ini adalah metode kualitatif.. Menurut Denzin dan Lincoln, dalam Moleoang $(2012,5)$ bahwa penelitian kualitatif adalah penelitian yang menggunakan latar alamiah, dengan maksud menafsirkan fenomena yang terjadi dan dilakukan dengan jalan melibatkan berbagai metode yang ada. Tehnik pengumpulan data melalui observasi, wawancara dan dakumentasi, sumber data meliputi sumber data primer dan data sekunder, tehnik penentuan informan penelitian menggunakan purposive sampling dengan informan kuncinya adalah orang-orang yang pernah melakukan migrasi interasional dan yang akan bermigrasi internasional yang ada di Desa Mekar Damai Kecamatan Praya Kabupaten Lombok Tengah. Sementara informan biasa adalah kepala desa, keluarga dekat dan masyarakat desa Mekar Damai. Tehnik analisis data yang digunakan Menurut Miles dan Huberman dalam Sugiyono 2014, adalah: Pengumpulan data, Reduksi data, Display data dan Verifikasi.

\section{HASIL PENELITIAN}

Berdasarkan hasil observasi dan wawancara yang telah dilakukan terhadap informan/responden bahwa factor yang mempengaruhi masyarakat Desa Mekar Damai Kecamatan Praya Kabupaten Lombok Tengah melakukan migrasi internasional terutama menjadi TKI adalah: Faktor ekonomi menjadi hal utama bagi mereka untuk melakukan migrasi internasional namun bukan berarti tidak terdapat faktor lain yang mempengaruhi mereka dalam melakukan migrasi internasional. Untuk lebih jelasnya beberapa hasil wawancara kami dengan informan penelitian dideskripsikan sebagai berikut:

Terdapat beberapa faktor yang mempengaruhi peningkatan migrasi internasional di Desa Mekar Damai Kecamatan Praya Kabupaten Lombok Tengah yaitu;

\section{Faktor Sosial.}

Laju pertumbuhan penduduk yang tinggi tidak diimbangi oleh perkembagan ekonomi., tingkat pendapatan masyarakat yg rendah, harga kebutuhan pokok yang semakin mahal, besarnya tanggugan keluarga dan sulitnya lapangan pekerjaan, hal ini menimbulkan masalah bagi kehidupan masyarakat, seperti; semakin terpuruknya perekonomian masyarakat, kemiskinan, banyaknya pengangguran. Kondisi ini menyebabkan sebagian masyarakat mengambil keputusan untuk melakukan migrasi internasional sebagai TKI (Tenaga Kerja Indonesia). Karena dengan bekerja sebagai TKI kehidupan para keluarga yang ditinggal berkecukupan dan bisa dibilang kesejahteraan ekonominya menjadi lebih baik. Hal ini didukung oleh hasil wawancara dengan informan yaitu keluarga TKI yang bernama Yuli Astuti, tanggal, 29 September 2015 yaitu;

Wawancara dengan anggota keluarga TKI Yuli Astuti di rumahnya oleh peneliti. Dia mengatakan, "Saya sangat bangga dengan 
bapak saya yang bekerja keras untuk saya dan keluarga meskipun saya harus pisah dengan beliau bekerja keluar negeri. Saya tidak malu punya bapak seorang TKI selama pekerjaannya halal. Jika bapak saya tidak bekerja keluar negeri tidak mungkin saya bisa melanjutkan sekolah, mendapatkan rumah yang bagus dan mempunyai kendaraan"

Kepergian anggota rumah tangga ke luar negeri sebagai TKI terbukti telah mampu meningkatkan taraf hidup keluarga. Kebutuhan konsumsi sehari-hari dapat terpenuhi dengan uang remetasi yang dikirimkan ke daerah asal. Sebagian besar TKI juga membangun dan memperbaiki rumah terutama setelah kebutuhan primernya terpenuhi. Selain itu, sebagian uang tersebut juga digunakan untuk keperluan investasi seperti pendidikan anak dan membeli asset produktif yang dapat menghasilkan pendapatan bagi rumah tangga antara lain lahan pertanian dan perkebunan serta membuka warung/toko yang menjual berbagai barang kebutuhan sehari-hari.

Perubahan sosial yang berkaitan dengan remetensi kelurga TKI dan ekonomi keluarga tenaga kerja Desa Mekar Damai yang menjadikan mereka memasuki kelas sosial menengah baru di kalangan masyarakat. Besar kecilnya jumlah remetasi oleh keluarga berpengaruh terhadap pola penggunaan remitensi oleh keluarga TKI.

Apa yang telah diuraikan diatas menjelaskan bahwa, eksistensi mobilitas penduduk, keadaan ekonomi yang tidak menentu dan remitasi sangat mempengaruhi keinginan masyarakat untuk melakukan migrasi internasional yang kemudian dapat mensenjahterakan keluarga.

Sementara hasil wawancara dengan informan lain yaitu; Pak Hamdi, tanggal 29 September 2015, sebagai berikut:

Saya sering melakukan migrasi internasional bolak balik dalam waktu yang lama. Ketika cuti pulang kerumah paling satu, dua, tiga bulan dan kadang sampai satu tahun setelah habis masa cuti pergi lagi. Disana saya bekerja dikebun sawit, jenis pekerjaan yang sangat berat tapi saya merasa nyaman bekerja disana disamping gajinya cukup besar ditambah dengan teman-teman yang baik dan teriri dari beberapa daerah".

Apa yang diuraikan diatas para tenaga kerja merasa nyaman dengan suasana lingkungan kerja yang menyenangkan dan gajinya yang sudah pasti ada dan cukup besar dari pada berada didalam negeri. Mereka yang berprofesi sebagai petani terkadang tidak mendapatkan hasil maksimal karena terjadi gagal panen di tambah lagi dengan musim kemarau yang sangat panjang. Sehingga hasil yang mereka dapatkan tiidak menentu. Sehingga mereka yang pernah pergi bekerja keluar negeri ingin kembali lagi pergi bekerja keluar negeri.

\section{Faktor Pendidikan}

Penguasaan teknologi dan ilmu pengetahuan bagi seseorang akan menjaminnya hidup lebih mudah. Bahkan orang yang berilmu akan diangkat derajatnya oleh allah SWT. Hal ini tidak akan didapatkan oleh seseorang jika tingkat pendidikannya kurang atau rendah. Factor pendidikan merupakan salah satu faktor selain factor social dan ekonomi yang mendorong keinginan seseorang untuk bermigran ke daerah lain terutama ke luar negeri yang dianggap lebih baik dan menguntungkan. Tingkat pendidikan juga dapat memepengaruhi kinerja dan produktivitas seseorang. Di Desa Mekar Damai hanya segelintir orang yang berkeinginan mencari ilmu keluar negeri.

M. Ismayadi adalah salah satu masyarakat Mekar Damai yang pernah melakukan migrasi internasional ke Negara Yaman dengan tujuan mencari ilmu. Pada saat diwawancarai oleh peneliti beliau menguturkan, " Saya memilih untuk mencari ilmu keluar negeri atas dorongan niat, dan motifasi dari keluarga. Pendidikan di luar negeri seperti di yaman kualitas pendidikannya lebih baik di bandingkan dinegeri sendiri terutama dalam ilmu agama yang saya tekuni" (Senin, 28 September 2015).

Dari keterangan diatas menggambarkan bahwa diluar negeri terlebih di Negara-negara maju, kualitas pendidikannya lebih baik dan fasilitasnya lebih lengkap, jika dibandingkan dengan pendidikan di Indonesia. Sehingga sebagian orang memilih untuk melanjutkan pendidikannya di luar negeri. Pendidikan merupakan sesuatu hal yang sangat penting untuk berkembangnya seseorang bahkan suatu Negara. Tanpa adanya sistem pendidikan yang baik, maka kemajuan suatu Negara akan terganggu. Sebenarnya kualitas SDM (Sumber Daya Manusia) di Indonesia sudah cukup bagus. Tinggal bagaimana cara pemerintah dan perguruan tiggi mengasah SDM mejadi SDM yg hebat. Terutama tenaga pengajar. Jika kualitas 
tenaga pengajar baik, maka akan mempengaruhi kualitas anak didiknya.

Berdasarkan hasil wawancara dengan Pak Aliman pada tanggal 29 September 2015 yang juga pernah sekolah keluar negeri mengatakan "Sekolah di luar negeri memeberikan banyak manfaat seperti dapat mengasah bahasa asing sehingga kita tidak perlu susah-susah kursus dan dilihat dari sisi referensi kita dapat banyak buku referensi yang belum tentu ada di negeri kita. Juga untuk mencari pengalaman baru, bagai mana proses pembelajaran disana kemudian dari pengalaman tersebut dapat saya ajarkan kepada peserta didik di negeri sendiri". Tambahnya lagi ia mengatakan". Saya tidak mempunyai tujuan untuk mendapatkan pekerjaan disana walaupun disana juga saya bekerja sambilan hitunghitung meringankan beban orang tua atau bisa dikatakan mandiri".

Manfaat sekolah diluar negeri sangat banyak jika dilihat dari beberapa sisi diantaranya adalah; dari sisi keilmuan, maka ia akan menggali lansung dari referensi induknya dengan bahasa asli penulisnya. Hal ini setidaknya akan membuka peluang untuk memperdalam orientasi ilmu dan ketajamannya, dari sisi rujukan ilmu, maka di luar negeri mungkin peluang-peluang untuk berguru atau bertanya lansung pada ilmuan dunia lebih terbuka, dari sisi jaringan, maka ia akan mempunyai banyak asset berupa jaringan untuk masa depan. Mungkin sesama mahasiswa Indonesia atau mahasiswa dari negeri lain. Perasaan senasib sepenanggungan bisa berbuah jaringan yang kuat di masa depan dan menguatkan persaudaraan.

\section{Faktor Ekonomi}

Pada umumnya setiap orang ingin mendapatkan penghidupan yang layak, namun tidak semua orang dapat memperolehnya, untuk mendapatkan penghidupan yang layak tersebut tentu harus ada usaha yang dilakukan. Salah satu usaha masyarakat Mekar Damai dalam memperoleh penghidupan yang layak yakni dengan cara menjadi TKI keluar negeri. Menjadi TKI dipandang sebagai cara yang cepat untuk merubah kehidupan terlepas dari segala resiko menjadi TKI di luar negeri.

Menjadi TKI ke luar negeri bukanlah hal yang baru dilakukan oleh masyarakat Desa Mekar Damai, sejak tahun 1997 masyarakat mulai menggemari menjadi TKI karena melihat keberhasilan masyarakat lain yang sudah pernah menjadi TKI keluar negeri. Sejak saat itu hingga saat ini masyarakat Desa Mekar Damai jumlahnya yang melakukan migrasi internasional terus meningkat terutama yang menjadi TKI. Berdasarkan data yang diperoleh dari kantor Desa Mekar Damai diperoleh jumlah TKI yang keluar negeri yang tercatat sejak tahun 20122014 menunjukkan adanya peningkatan jumlahnya. Berikut uraian tabel jumlah migrasi internasional.

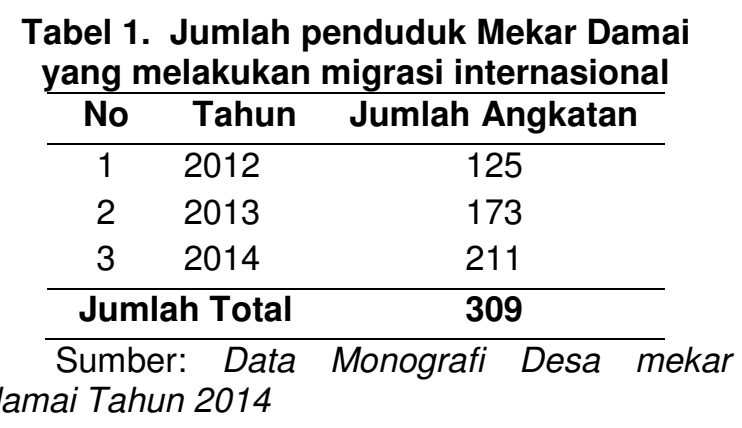

Terjadinya peningkatan jumlah penduduk desa Mekar Damai yang melakukan migrasi internasional terutama menjadi TKI ke luar negeri dengan alasan faktor ekonomi adalah kebanyakan jawaban yang diungkapkan oleh informan yang pernah menjadi TKI.

Sebagai mana kondisi ekonomi masyarakat Desa mekar Damai, baik dari angkatan kerja, rata-rata mata pencaharian, penduduk dan tingakt kesejahteraan masyarakat, masih menunjukkan kategori yang rendah. Hal ini terkait dengan rendahnya tingkat pendidikan penduduk dan tidak seimbangnya jumlah tenaga kerja dengan jumlah lapangan pekerjaan yang tersedia, sehingga dapat mempengaruhi banyaknya pekerja migran di desa Mekar Damai.

Hal ini senada dengan jawaban bapak Baharudin saat diwawancarai di kediamanya, yang menyatakan bahwa faktor yang mempengaruginya melakukan migrasi internasional adalah faktor ekonomi, "Saya memiliki dua anak dan istri yang menjadi tanggugan, bekerja sebagai buruh bagunan di desa mekar damai ini penghasilanya tak menentu sehingga pendapatan tidak cukup untuk membiayai kehidpan dan menyekolahkan anak. Dengan alasan tersebut saya memutuskan untuk melakukan migrasi internasonal khususnya menjadi TKI ke Malasyia, disana saya bekerja di perkebunan 
kelapa sawit" (hari Jum'at taggal 25 September 2015).

Dari keterangan bapak Baharudin diatas, bahwa faktor ekonomi membuatnya melakukan migrasi internasional khususnya menjadi TKI ke Malasyia. Beban tanggungan keluarga mengharuskannya melakukan migrasi internasional terlepas dari bayang-bayang resiko hidup di Negara orang. Selain bapak Baharudin, masih banyak orang lain yang melukukan migrasi untuk menjadi TKI keluar negeri dengan alasan yang sama yaitu karena akonomi keluarga.

Bapak H. Hamdi merupakan salah satu warga desa Mekar Damai yang sudah pernah melakukan migrasi internasional ke Malasiya, Saudi Arabiah dan Brunai Darusalam dengan alasan faktor ekonomi juga, saat di wawancarai di kediamanya oleh peneliti bapak H.Hamdi menerangkan, "Saya sudah pernah ke tiga Negara berbeda untuk bekerja sebagai TKI ke luar negeri karena alasan ekonomi, di desa mekar damai ini saya hanya memiki lahan 30 are, itupun bukan lahan produtif, ketika saya mengelolanya hasilnya tidak seberapa dibandingkan dengan kebutuhan keluarga. Selain mengelola lahan sendiri saya juga menjadi buruh tani namun tidak cukup juga, hal ini membuat saya mimilih melakukan migrasi internasional kebergai negara demi mendapatkan penghidupan yang layak bagi keluarga saya"(27 September 2015).

Pengalaman bapak $\mathrm{H}$. Hamdi ke beberapa negara di atas bukan untuk jalan-jalan akan tetapi untuk mencari penghasilan yang lebih bagi keluarganya. Kasus berbeda terjadi dengan bapak Pidi yang melakukan migrasi internasional walaupun memiliki sebidang lahan dan memiliki penghasilan yang cukup untuk memenuhi kebutuhan sandang, pangan, dan papan. Walaupun demikian keputusan untuk melakukan migrasi ke malasyia diambilnya.

Dari hasil wawancancara dengan bapak Pidi dirumahnya, "Walaupun saya memiliki sebidang lahan untuk dikelola dan terbilang cukup untuk memenuhi kebutuahan hidup, namun anak saya yang memiliki keinginan melanjutkan sekolah ke perguruan tinggi, mengharuskan saya untuk pergi mengingat biaya pendidikan di perguruan tinggi yang mahal, penghasilan dengan mengelola sawah tersebut tidaklah cukup. Oleh karena itu saya pergi kemalasyia setidaknya sampai biaya untuk pendidikan anak saya cukup dan saya akan kembali" (27 September 2015).
Migrasi yang dilakukan tidak hanya dilakukan oleh mereka yang tidak memiliki banyak lahan produktif di desanya, namun juga warga yang memiliki sebidang lahan untuk dikelola tetapi dipandang tidak cukup bila ada anaknya yang melanjutkan pendidikan ke perguruan tinggi. Dengan demikian keputusan untuk melakukan migrasi internasional dilakukan untuk membiayai pendidikan anaknya.

\section{PEMBAHASAN}

Berdasarkan pada hasil penelitian yang dilakukan maka faktor-faktor yang mempengaruhi peningkatan migrasi internasional masyarakat di desa Mekar Damai Kecamatan Praya Kabupaten Lombok Tengah adalah sebagai berikut:

1. Faktor Sosial; Hakekat manusia adalah sebagai makhluk individu sekaligus sebagai makhluk sosial. Sebagai makhluk sosial setiap individu dalam menjalani hidup berinteraksi dengan orang lain atau sering kita kenal dengan sebutan relasi interpersonal. Begitu juga dengan masyarakat Mekar Damai, proses interaksi warga sangat tinggi. Melalui interaksi inilah mereka mendapatkan informasi tentang peluang menjadi TKI, dengan upah yang cukup menjanjikan kesejahteraan. Sebagian besar masyarakat Mekar Damai berprofesi menjadi buruh tani yang tingkat upahnya tidak sebanding dengan biaya kebutuhan keluarga seperti pendidikan, kesehatan ,sandang, pangan dan papan. Keadaan demikian memicu warga masyarakat untuk mencari pekerjaan yang layak untuk dapat memenuhi kebutuhan tersebut dengan melakukan migrasi internasional. Menjadi TKI bukanlah suatu keputusan yang mudah, mereka harus meninggalkan tanah kelahiran, keluarga dan kerabat dalam waktu yang relatif lama. Namun disamping itu ada beban utama yang harus terpenuhi terutama bagi seorang kepala keluarga, sehingga tidak ada pilihan lain selain melakukan migrasi internasional.

Kebanyakan warga masyarakat Mekar Damai yang melakukan migrasi internasional dari kalangan usia muda dan yang sudah menikah. Usia muda, antara 20-30 tahun keinginnan untuk keluar lingkungan sosial lebih besar dan pada usia itulah biasanya mulai memasuki usia kerja. Mereka yang berstatus menikah lebih condong untuk mencari pekerjaan dari 
pada yang belum menikah, karena adanya tanggungjawab terhadap pemenuhan kebutuhan keluarga mendorong seorang yang berstatus menikah untuk bekerja, sehingga sebagian besar para TKI/TKW yang ada di desa Mekar Damai adalah mereka yang berusia muda yang sudah menikah.

2. Faktor Pendidikan; Pendidikan merupakan dasar utama membentuk kepribadian seseorang, bahkan untuk meningakatkan potensi ekonomi Negara dengan meningkatkan potensi SDM (Sumber Daya Manusia) melalui pendidikan. Pendidikan masyarakat Mekar Dami secara umum masih tergolong rendah, namun tidak sedikit yang mengenyam pendidikan tinggi. Melihat kondisi kualitas pendidikan diatas mendorong segelintir masyarakat desa Mekar Damai yang tergolong mampu dalam ekonomi dan kecerdasan, memilih untuk meningkatkan pendidikan yang lebih tinggi ke luar negeri. Dengan alasan, kualitas pendidikan luar negeri lebih baik dibandingkan didaerah sendiri, dan fasilitasnya lebih lengkap serta mendapatkan pengalaman yang banyak sehinnga dapat diamalkan didaerah sendiri. Bukan hanya itu belajar di luar negeri dapat dijadikan motivasi kepada guru dan para pelajar akan pentingnya pendidikan walaupun harus mencarinya kenegeri orang.

3. Ekonomi; Kondisi ekonomi masyarakat desa Mekar Damai dilihat dari mata pencaharian, tingkat kesejahteraan masyarakat masih menunjukkan kategori rendah, hal ini berkaitan pula dengan rendahnya tingkat pendidikan penduduk. Ujung dari setiap alasan masyarakat desa Mekar Damai melakukan migrasi internasional adalah faktor ekonomi. Kemiskinan menjadi penyebab utama pemicu masyarkat Mekar Damai bekerja keluar negeri. Mereka menjadi miskin bukan mereka malas bekerja atau karena budaya miskin, tetapi lebih karena kurangnya penyediaan lapangan pekerjaan juga minimnya upah para buruh dan rendahnya kualitas sumber daya manusia karena tingkat pendidikan (keterampilan) rendah. Melihat harga barang kebutuhan semakin mahal, biaya pendidikan dan kesehatanpun tinggi. Mendorong mereka untuk berusaha mencari pekerjaan yang lebih baik yang upahnya lebih tinggi sehingga kebutuhan keluarga tercukupi.. Keterbatasan lapangan pekerjaan membuat arus migrasi internasional semakin tinggi di desa Mekar Dami, karena diwilayah asal mereka yaitu pedesaan, mereka tidak bisa mendapatkan nafkah lebih, disebabkan wilayah pertanian, hasilnya tidak bisa dinikmati secara lansung atau continue mereka harus menunggu dalam waktu lama untuk mereka bisa menikmati hasil panennya. Sementara bekerja di luar negeri walaupun sebagai TKI menjanjikan upah yang memadai yang didperoleh dalam waktu singkat., karena gaji/upah yang akan mereka terima perbulannya mereka rasakan akan mencukupi kebutuhan keluarganya hal itulah yang membuat mereka tertarik melakukan migrasi internasional.

\section{SIMPULAN DAN SARAN}

A. Simpulan.

Berdasarkan hasil penelitian yang dilakukan, bahwa faktor yang mempengaruhi peningkatan migrasi internasional di desa Mekar Damai Kecamatan Praya Kabupaten Lombok Tengah yaitu: (1) Faktor Sosial; Keinginan untuk merubah status sosial keluarga merupakan salah satu yang menyebabkabkan sebagian masyarakat desa Mekar Damai melakukan migrasi internasional dalam kurun waktu beberapa tahun terakhir; (2) Faktor Pendidikan, selain faktor sosial faktor pendidikan juga merupakan faktor yang mempengaruhi migrasi internasioan masyarakat di desa Mekar Damai walaupun dilakukan hanya oleh beberapa orang/sebagaian kecil saja dari masyarakat. Asyarakat desa Mekar Damai melanjutkan studi di luar negeri dengan alasan kualitas pendidikan di luar negeri lebih baik dibandingkan dengan di dalam negeri selain tu juga alasan mencari pengalaman baru. (3) Faktor Ekonomi; Masyarakat desa Mekar Damai pendapatannya berasal dari pertanian, namun banyak diantara masyarakatnya menjadi buruh tani yang hasilnya tidak menentu. Himpitan ekonomi yang semakin mencekik, kebutuhan keluarga semakin tinggi, harga kebutuhan pokok semakin mahal, dan sulitnya lapangan pekerjaan di dalam negeri, membuat masyarakat desa Meker Damai terpaksa mencari pekerjaan di luar negeri untuk memenuhi kebutuhan hidupnya beserta keluarga. 


\section{B. Saran.}

1 Diharapka bagi Pemerintah pusat atupun daerah lebih memperhatikan dan memperbaiki kondisi ekonomi negara, kualitas pendidikan dan menyediakan lapangan pekerjaan untuk masyarakat.

2 Bagi Peneliti Selanjutnya, hendaknya melakukan penelitian lebih lanjut menganai hal-hal yang belum terungkap dalam penelitian ini, sehingga perlindungan terhadap pekerja/buruh dalam sistim perjanjian kerja waktu tertentu dapat ditingkatkan lagi.

\section{DAFTAR PUSTAKA}

Befita,P.2014."Analisis Tentang Determinan Migrasi internasional". Diambil Tanggal 27 April 2015. Dari

http//www.ac.id/index.php/JSEP/article/d ownload/380/238

Bakar, W.A,2014 Migrasi Internasional Kontribusinya Terhadap Daerah Asal. Diambil pada tanggal 29 april 2015.dari http//www.eprits.undip.id

Herwati, T.2011.Pengeruh Pendapatan Lama Bekerja Dan Status Family Terhadap Remitan Tenaga Kerja Wanita Propinsi Nusa Tenggara Barat, Vol.15.No. 26, Maret 2011. Diambil pada tanggal 27 April 2015 dari http//www.lish.huggins@
Husni.2007.Hukum Penempatan Dan Perlindungan TKI.Malang.Program Pasca Sarjana Universitas Brawijaya Malang.
Ida Bagoes Mantra.2009.Demografi Umum.Pustaka Pelajar.Yogyakarta.

Listiarini, N. 2011. Faktor Individual Yang Mempengaruhi Minat Migrasi, vol. 11. Diambil pada tanggal 24 april 2015 dari http//www.eprints.undip.id.

Muslan, A.2006. Ketidak Patuhan TKI.UMM Prees. Malang.
Moleong, J.2012. Metodologi Penelitian Kualitatif. PT Remaja Rosdakarya. Bandung

Sugiono.2014.Metode Penelitian Pendidikan, Pendekatan Kualitatif dan $R \& D$.Alfabet. Bandung.

Nining, P.2011.Faktor-Faktor Yang Memepengaruhi Tenaga Kerja Wanita Bekerja Di Luar Negeri. Diambil pada tanggal 29 april 2015 dari http// eprints.undip.ac.id/26649/1/JURNAL_C 2B006046.pdf

Waridin.2003.Pola Migrasi Tenga Kerja Indonesia (TKI) Keluar Negeri, vol.4.no1, 28 April 2015 dari http//www.lish.huggins. 